\title{
Epidemiological characterization of $P$. aeruginosa isolates of intensive care units in Egypt and Saudi Arabia
}

\author{
S.A. Mansour, ${ }^{1}$ O. Eldaly, ${ }^{1}$ A. Jiman-Fatani, ${ }^{2}$ M.L. Mohamed ${ }^{3}$ and E.M. Ibrahim ${ }^{4}$
}

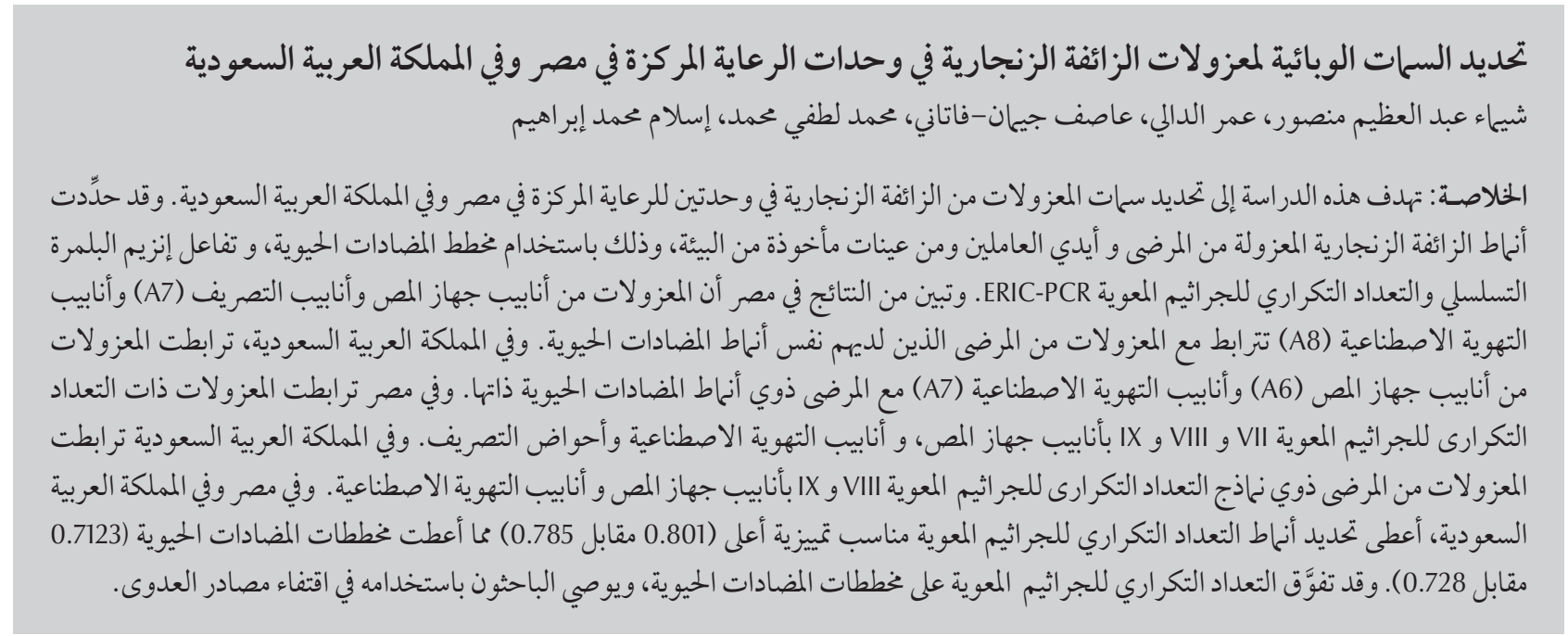

ABSTRACT This study aimed to characterize Pseudomonas aeruginosa isolates in 2 intensive care units in Egypt and Saudi Arabia. P. aeruginosa isolates from patients' and staff hands and environmental samples were typed using antibiotyping and ERIC-PCR. In Egypt, isolates from suction apparatus tubing and drainage containers (A7) and AV tubing (A8) were linked to those from patients who had these antibiotypes. In Saudi Arabia, isolates from suction apparatus tubing (A6) and AV tubing (A7) were linked to patients with the same antibiotypes. In Egypt, patients' isolates had ERIC VII, VIII and IX patterns linked to suction apparatus tubing, AV machine tubes and drainage containers. In Saudi Arabia, patients' isolates had ERIC VIII and XI patterns linked to suction apparatus tubing and AV machines. In Egypt and Saudi Arabia, ERIC typing gave higher discriminatory indices ( 0.801 and 0.785 respectively) than the antibiotyping ( 0.7123 and 0.728 respectively). ERIC was superior to antibiotyping and should be used in tracing sources of infection.

\section{Caractérisation épidémiologique d'isolats de Pseudomonas aeruginosa dans des unités de soins intensifs en Arabie saoudite et en Égypte}

RÉSUMÉ La présente étude visait à caractériser des isolats de $P$. aeruginosa dans deux unités de soins intensifs en Arabie saoudite et en Égypte. Des isolats de $P$. aeruginosa prélevés sur les mains du personnel et des patients et des échantillons environnementaux ont été typés par antibiogramme et ERIC-PCR. En Égypte, des isolats prélevés sur les tubulures d'appareils d'aspiration et de respiration artificielle (A8) et sur les cuvettes (A7) étaient liés à ceux prélevés chez les patients ayant ces antibiotypes. En Arabie saoudite, des isolats prélevés sur des tubulures des appareils d'aspiration (A6) et de respiration artificielle (A7) étaient liés à ceux prélevés chez les patients ayant les mêmes antibiotypes. En Égypte, les isolats des patients étaient de types ERIC VII, VIII et IX et correspondaient à ceux des tubulures des appareils d'aspiration et de respiration artificielle et des cuvettes. En Arabie saoudite, les isolats des patients étaient de types ERIC VIII et XI correspondaient à ceux des tubulures des appareils d'aspiration et de respiration artificielle. En Égypte et en Arabie saoudite, le typage ERIC a permis d'obtenir des index de discrimination supérieurs $(0,801$ et 0,785 respectivement) à ceux de l'antibiogramme $(0,7123$ et 0,728 respectivement). La méthode ERIC était supérieure à l'antibiotypage et devrait être utilisée pour déterminer les sources d'infection.

${ }^{7}$ Department of Medical Microbiology and Immunology; ${ }^{3}$ Department of Obstetrics and Gynaecology; ${ }^{4}$ Department of General Surgery, Faculty of Medicine, University of Zagazig, Zagazig, Egypt(Correspondence to S.A. Mansour: shymaa_abdelazim@yahoo.com).

${ }^{2}$ Department of Medical Microbiology, King Abdulaziz University, Jeddah, Saudi Arabia.

Received: 05/09/11; accepted: 18/01/12 


\section{Introduction}

The Gram-negative bacterium Pseudomonas aeruginosa is frequently associated with hospital-acquired infections in intensive care units (ICUs) [1]. It has been identified as the 2 nd most frequent organism causing ventilatorassociated pneumonia, the 4th most common causing catheter-associated urinary tract infections, the 5 th cause of surgical site infections and the 7 th cause of central-line-associated bloodstream infections [2]. P. aeruginosa has inherent resistance to many drug classes $[3,4]$. Moreover, it can acquire resistance via mutations and harbouring integrons with multiple resistance genes such as those coding for metallo- $\beta$-lactamases (MBL) that can cleave the most active antimicrobial agents against it (carbapenems) [3].

The source of $P$. aeruginosa in intensive care units (ICUs) can be either endogenous or exogenous; isolates that have unique genotypes are considered as possibly endogenous while those of the same genotype with either patient or environmental samples are considered as possibly exogenous [5]. Optimal control of $P$. aeruginosa outbreaks may require rapid identification and strain differentiation. Traditionally, it has been typed on the basis of its phenotypic characteristics but this technique may lack discriminatory power and stability [6]. Molecular techniques offer a considerable improvement, and can complement phenotypic data to obtain a better understanding of bacterial diversity [7]. Pulsed field gel electrophoresis is commonly employed and has achieved widespread recognition as the gold standard for P. aeruginosa deoxyribonucleic acid (DNA) typing $[8,9]$. However, this method is limited by its technical complexity, expense and prolonged turnaround times for results [7]. As an alternative, repetitiveelement-based polymerase chain reaction (rep-PCR) assays that utilize primers targeting highly-conserved repetitive sequence elements in the bacterial genome have shown considerable potential as DNA typing tools in the laboratory [10]. One of such groups of repetitive elements is the enterobacterial repetitive intergenic consensus (ERIC) sequences which are common to Gram-negative enteric bacteria $[11,12]$. The products of ERICPCR, with chromosomal DNA of different bacterial strains, were found to generate very characteristic patterns when separated on agarose gels. Thus, it has been proposed that ERIC-PCR is a useful method to fingerprint bacterial genomes [13].

This work was designed to elucidate the epidemiology of $P$. aeruginosa isolates in ICUs in both Egypt and Saudi Arabia and to identify MBL-producing isolates. It also aimed to compare typing methods by antibiogram and ERICPCR for their discriminatory power and compatibility.

\section{Methods}

This study was conducted in the Department of Medical Microbiology and Immunology, Faculty of Medicine, University of Zagazig, Egypt and the Department of Medical Microbiology, King Abdulaziz University, Saudi Arabia in the period from January 2009 to December 2010. This study was approved by the ethics committees of Zagazig University Hospital and King Abdulaziz University.

\section{Study sample}

A total of 270 samples were collected from patients, staff hands and the environment from surgical adult ICUs of both hospitals:

- 180 samples were collected from patient sources, including $30 \mathrm{spu}$ tum, endotracheal aspirate, blood, wound exudate, burn exudate and urine specimens.

- 30 samples were collected from staff hands at midday, by which time staff members had been in contact with patients for several hours. For each staff member $30 \mathrm{~mL}$ of sterile nutrient broth was poured into a sterile plastic bag and the hands were massaged in the broth for $30 \mathrm{~s}$ [14].

- 60 environmental samples were taken throughout the ICU, including water taps, faucet handles, drainage containers, mops, manual resuscitation bags, AV tubing, suction apparatus tubing, air condition outlets and antiseptic solutions. Surfaces were swabbed with sterile cotton swab sticks and fluid samples were pipetted using sterile disposable plastic pipettes.

\section{Isolation and identification of $P$. aeruginosa}

Blood samples were used for inoculating blood culture bottles (Egyptian Diagnostic Media) then incubated at $37^{\circ} \mathrm{C}$ for 7-14 days. Subcultures were done every $48 \mathrm{~h}$ on blood agar plates. Sputum, endotracheal aspirate, wound exudate, burn exudate and urine specimens were cultured on Pseudomonas cetrimide agar (Oxoid).Pseudomonas spp. isolates were subcultured on nutrient agar plates at $37^{\circ} \mathrm{C}$ for $24 \mathrm{~h}$ to identify the growth characters. For analysis of staff hand specimens, a loopful sample of the broth was cultivated. Environmental samples were cultured in nutrient broth to dilute any disinfectants present and to encourage growth of low organism numbers. After $24 \mathrm{~h}$ incubation, subcultures were made onto Pseudomonas cetrimide agar plates and incubated at $37^{\circ} \mathrm{C}$. Any growth was identified as $P$. aeruginosa if it has the following criteria: characteristic colony morphology, grape-like odour, exopigments production [15], Gramnegative motile bacilli, positive oxidase test (Oxoid code BR0064A), growth at $42^{\circ} \mathrm{C}$ [16], gelatin liquefaction test positive [17] and red butt and slant of triple sugar-iron medium [18].

\section{Antibiogram}

Antibiotic resistance testing was done by the Kirby-Bauer disk diffusion 
method according to Clinical Laboratory Standards Institute guidelines [19]. The following antibiotics (Oxoid) were used: piperacillin $100 \mu \mathrm{g}$, ceftazidime $30 \mu \mathrm{g}$, cefepime $30 \mu \mathrm{g}$, aztreonam $30 \mu \mathrm{g}$, imipenem $10 \mu \mathrm{g}$, meropenem $10 \mu \mathrm{g}$, colistin $25 \mu \mathrm{g}$, amikacin $30 \mu \mathrm{g}$, gentamycin $10 \mu \mathrm{g}$, tobramycin $10 \mu \mathrm{g}$ and ciprofloxacin $5 \mu \mathrm{g}$. Screening for MBLs was performed by the imipenemEDTA combined-disk test as described by Yong et al. [20].

\section{PCR methods}

\section{DNA extraction}

All strains were freshly cultured on nutrient agar before DNA extraction using the QIAamp DNA mini kit (Qiagen $\mathrm{GmbH}$ ) according to the manufacturer's instructions. The extracts were then kept at $-20^{\circ} \mathrm{C}$ until use.

\section{ERIC-PCR typing}

ERIC-PCR typing was performed as reported previously [21] using PCRGOLD Master-Mix Beads (Bioron, The Enzyme Company). The following materials were added to each PCR bead: 50 ng of DNA template, 10 pmole of each primer (Bioneer ${ }^{\mathrm{m}}$ Corporation); ERIC1R (5'ATG TAA GCT CCT GGG GAT TCA C $3^{\prime}$ ) and ERIC2 (5'AAG TAA GTG ACT GGG GTG AGC G 3') [22] and deionized distilled water to a final volume of $50 \mu \mathrm{L}$. These were mixed well by automatic pipette, followed by brief centrifugation to collect the contents at the bottom of the tube. For the negative control reaction, all components of PCR reaction were added to the bead except for DNA to exclude any source of contamination. The gene segments were amplified using a DNA thermal cycler (Biometra). The reaction conditions were as follows: initial denaturation at $94^{\circ} \mathrm{C}$ for $1 \mathrm{~min}$, followed by 35 cycles of denaturation at $94{ }^{\circ} \mathrm{C}$ for $45 \mathrm{~s}$, annealing at $52^{\circ} \mathrm{C}$ for $45 \mathrm{~s}$ and DNA chain extension at $72{ }^{\circ} \mathrm{C}$ for $2 \mathrm{~min}$, and a final extension at $72^{\circ} \mathrm{C}$ for $10 \mathrm{~min}$.
DNA detection by agarose gel electrophoresis

Amplification products and DNA molecular weight marker (GeneRuler $^{\text {ox }} 1$ kb Plus ${ }^{\circ}$ ) were detected by using agarose gel electrophoresis [23]. These were visualized on a UV transilluminator (Biometra) and photographed.

\section{Statistical analysis}

All data were tabulated and then processed using SPSS, version 12.0. Qualitative variables were expressed by percentages and compared using the chi-squared test or Fisher exact test when appropriate. A $P$-value < 0.05 was considered statistically significant. The numerical discriminatory index, which is a measure of the discriminatory ability of the typing methods was calculated according to Hunter [24].

\section{Results}

\section{Isolation rate of $\boldsymbol{P}$. aeruginosa}

Table 1 shows that in Egypt and Saudi Arabia, $P$. aeruginosa was isolated from $32.8 \%$ and $30.0 \%$ of patient samples respectively. In Egypt, the highest isolation rate was from burn exudates (66.7\%), while in Saudi Arabia, it was from endotracheal aspirates (36.7\%). There was a statistically significant difference between data from Egypt and Saudi Arabia only in the rate of isolation of $P$. aeruginosa from burn exudates $(P$ $=0.02$ ).

The isolation rate of $P$. aeruginosa from environmental samples in Egypt was $25.0 \%$ overall and was highest (57.1\%) from suction apparatus tubing (Table 1). In Saudi Arabia, it was 23.3\% overall and was highest from suction apparatus tubing and artificial ventilation machine tubes ( $42.9 \%$ ).

Table 1 shows that $10.0 \%$ and $6.7 \%$ of staff hand samples from Egypt and Saudi Arabia respectively were culture positive

\section{Risk factors for acquiring $P$. aeruginosa}

Table 2 shows the univariate analysis of risk factors for acquiring $P$. aeruginosa infection based on analysis of patient samples in Egypt and Saudi Arabia. There were statistically significant difference as regards age $\geq 60$ years $(P=0.04$ in Egypt; $P<0.001$ in Saudi Arabia), length of hospital stay $\geq 7$ days $(P<0.001$ in both countries $)$, cancer in Egypt only $(P=0.01)$, surgery $(P<0.001$ in both countries $)$ and use of antibiotics $\geq 2$ days $(P=$ 0.009 in Egypt; $P<0.001$ in Saudi Arabia).

\section{Antibiotic resistance}

Table 3 reveals that antibiotic resistance rates of clinical isolates in Egypt and Saudi Arabia were highest to aztreonam (96.6\% and 98.1\%), followed by cefepime $(76.3 \%)$ and tobramycin $(67.8 \%)$ in Egypt, and followed by meropenem $(72.2 \%)$ and ceftazidime (70.4\%) in Saudi Arabia. On the other hand, the resistance rate of environmental isolates was $100 \%$ to aztreonam and ceftazidime in Egypt and ceftazidime and cefepime in Saudi Arabia (Table 3). Colistin was the only antibiotic to which nearly all strains were sensitive.

Table 4 shows the frequency of MBL-producing imipenem-resistant strains was 16/29 (55.2\%) in Egypt and 36/54 (66.7\%) in Saudi Arabia from clinical isolates, was $2 / 3$ (66.7\%) from environmental strains and was not detected in staff hand strains in either Egypt or Saudi Arabia. These differences were statistically significant $(P<$ 0.001 ) in the same country.

\section{Antibiotyping}

Tables 5 and 6 shows the antibiotyping of isolates, showing 9 antibiotype patterns in Egypt and 8 in Saudi Arabia, ranging from pattern $A 1$, which was sensitive to all tested antibiotics to pattern $A 9$ and $A 8$ which were resistant to all tested antibiotics except colistin. In 


\begin{tabular}{|c|c|c|c|c|c|c|}
\hline \multirow[t]{3}{*}{ Source } & \multirow{3}{*}{$\begin{array}{c}\text { No. of } \\
\text { samples }\end{array}$} & \multicolumn{4}{|c|}{ P. aeruginosa isolates } & \multirow[t]{3}{*}{$P$-value } \\
\hline & & \multicolumn{2}{|c|}{ Egypt } & \multicolumn{2}{|c|}{ Saudi Arabia } & \\
\hline & & No. & $\%$ & No. & $\%$ & \\
\hline \multicolumn{7}{|l|}{ Patient samples } \\
\hline Burn exudates & 30 & 20 & 66.7 & 11 & 36.7 & 0.02 \\
\hline Wound exudates & 30 & 11 & 36.7 & 10 & 33.3 & 0.78 \\
\hline Blood & 30 & 9 & 30.0 & 5 & 16.7 & 0.22 \\
\hline Urine & 30 & 8 & 26.7 & 9 & 30.0 & 0.77 \\
\hline $\begin{array}{l}\text { Endotracheal aspirate from patients with } \\
\text { ventilator associated pneumonia. }\end{array}$ & 30 & 6 & 20.0 & 11 & 36.7 & 0.15 \\
\hline Sputum & 30 & 5 & 16.7 & 8 & 26.7 & 0.34 \\
\hline Total & 180 & 59 & 32.8 & 54 & 30.0 & 0.57 \\
\hline \multicolumn{7}{|l|}{ Environment samples } \\
\hline Suction apparatus tubing & 7 & 4 & 57.1 & 3 & 42.9 & 1.00 \\
\hline Drainage container & 7 & 3 & 42.9 & 2 & 28.6 & 1.00 \\
\hline Artificial ventilation tubing & 7 & 2 & 28.6 & 3 & 42.9 & 1.00 \\
\hline Mops & 6 & 2 & 28.6 & 1 & 20.0 & 1.00 \\
\hline Air condition outlet & 5 & 1 & 20.0 & 2 & 28.6 & 1.00 \\
\hline Manual resuscitation bags & 7 & 1 & 20.0 & 2 & 28.6 & 1.00 \\
\hline Faucet handles & 7 & 1 & 20.0 & 1 & 20.0 & 1.00 \\
\hline Water tap & 7 & 1 & 20.0 & 0 & 0.0 & 1.00 \\
\hline Antiseptic solutions & 7 & 0 & 0.0 & 0 & 0.0 & 1.00 \\
\hline Total & 60 & 15 & 25.0 & 14 & 23.3 & 0.83 \\
\hline \multicolumn{7}{|l|}{ Staff hand samples } \\
\hline Total & 30 & 3 & 10.0 & 2 & 6.7 & 1.00 \\
\hline
\end{tabular}

Egypt, there were epidemiological relationships between suction apparatus tubing and drainage containers (A7) and artificial ventilation (AV) machine tubes (A8) and patients who had A7 and $\mathrm{A} 8$ antibiotypes; however, there was no direct link between isolates from staffhands (A1 and A2) and patients. In Saudi Arabia, there were relationships between antibiotypes of suction apparatus tubing (A6) and AV machine tubes (A7) and patients where they had A6 and A7 antibiotypes but there was no direct link between isolates from staff hand (A3 and $\mathrm{A} 4)$ or patients.

\section{ERIC-PCR typing}

$P$. aeruginosa isolates were typeable by ERIC-PCR and yielded 15 and 12 ERIC patterns from Egypt and Saudi Arabia respectively, with 4 to 11 bands in Egypt (Figure 1) and 3 to 9 bands in Saudi Arabia (Figure 2). The size of amplified DNA bands ranged from 110 bp to $1535 \mathrm{bp}$.

From ERIC-PCR typing methods MBL-producing strains showed epidemiological relationships among 3 sites in Egypt: suction apparatus tubing, AV tubing and drainage container (ERIC VII, VIII and IX genetic patterns respectively). In Saudi Arabia, we found links to suction apparatus tubing and AV machine sites (ERIC VIII and XI genetic patterns respectively).

On calculating the discriminatory index of both typing methods (antibiotyping and ERIC), we found that ERIC typing gave a higher discriminatory index in Egypt and Saudi Arabia (0.801 and 0.785 respectively) than the antibiogram ( 0.712 and 0.728 respectively) (Table 7).

\section{Discussion}

In spite of significant changes in the spectrum of organisms causing nosocomial infections in ICUs, $P$. aeruginosa has held a nearly unchanged position as an important pathogen [2]. In Egypt and Saudi Arabia, the rate of isolation from patient samples was $32.8 \%$ and $30.0 \%$ respectively. This in agreement with rates reported in Egypt by Ashour et al. (30.0\%) [25] and Gad et al. (24.0\%) [26] and in Saudi Arabia by Al Johani et al. (30.6\%) [27]. In Egypt, the highest isolation rate from patient samples was from burn exudates (66.7\%). This in accordance with Gad et al. (72.0\%) [24] and may be attributed to inappropriate infection control measures to burn patients. On the other hand, in Saudi Arabia, isolation was highest from endotracheal aspirates 


\begin{tabular}{|c|c|c|c|c|c|c|c|c|c|c|}
\hline \multirow[t]{3}{*}{ Variable } & \multicolumn{4}{|c|}{$\begin{array}{c}\text { Egypt } \\
(n=180)\end{array}$} & \multirow[t]{3}{*}{$P$-value } & \multicolumn{4}{|c|}{$\begin{array}{l}\text { Saudi Arabia } \\
\quad(n=180)\end{array}$} & \multirow[t]{3}{*}{$P$-value } \\
\hline & \multicolumn{2}{|c|}{$\begin{array}{c}\text { Infected } \\
(n=59)\end{array}$} & \multicolumn{2}{|c|}{$\begin{array}{l}\text { Non-infected } \\
\qquad(n=121)\end{array}$} & & \multicolumn{2}{|c|}{$\begin{array}{c}\text { Infected } \\
(n=54)\end{array}$} & \multicolumn{2}{|c|}{$\begin{array}{l}\text { Non-infected } \\
\qquad(n=126)\end{array}$} & \\
\hline & No. & $\%$ & No. & $\%$ & & No. & $\%$ & No. & $\%$ & \\
\hline \multicolumn{11}{|l|}{ Sex } \\
\hline Female & 24 & 40.7 & 51 & 42.1 & 0.85 & 20 & 37.0 & 41 & 32.5 & 0.55 \\
\hline Male & 35 & 59.3 & 70 & 57.9 & & 34 & 63.0 & 85 & 67.5 & \\
\hline \multicolumn{11}{|l|}{ Age (years) } \\
\hline $12-20$ & 7 & 11.9 & 20 & 16.5 & & 6 & 11.1 & 18 & 14.3 & \\
\hline $20-40$ & 26 & 44.1 & 68 & 56.1 & & 19 & 35.2 & 75 & 59.5 & \\
\hline $40-60$ & 18 & 30.5 & 28 & 23.1 & & 19 & 35.2 & 31 & 24.6 & \\
\hline$\geq 60$ & 8 & 13.5 & 4 & 3.3 & 0.04 & 10 & 18.5 & 2 & 1.6 & $<0.001$ \\
\hline \multicolumn{11}{|c|}{ Length of hospital stay (days) } \\
\hline$\geq 7$ & 55 & 93.2 & 39 & 32.2 & $<0.001$ & 50 & 92.6 & 63 & 50.0 & $<0.001$ \\
\hline \multicolumn{11}{|l|}{ Comorbid conditions } \\
\hline Diabetes mellitus & 16 & 27.1 & 26 & 21.5 & 0.4 & 10 & 18.5 & 20 & 15.9 & 0.66 \\
\hline Cardiac disease & 10 & 16.9 & 36 & 29.8 & 0.06 & 16 & 29.6 & 42 & 33.3 & 0.11 \\
\hline Cancer & 9 & 15.3 & 4 & 3.3 & 0.01 & 5 & 9.3 & 9 & 7.1 & 0.76 \\
\hline Trauma & 16 & 27.1 & 27 & 22.3 & 0.47 & 18 & 33.3 & 26 & 20.6 & 0.06 \\
\hline Surgery & 30 & 50.8 & 26 & 21.5 & $<0.001$ & 39 & 55.7 & 24 & 19.0 & $<0.001$ \\
\hline \multicolumn{11}{|c|}{ No. of antibiotics used } \\
\hline$\geq 2$ & 36 & 61.0 & 49 & 40.5 & 0.009 & 45 & 64.2 & 53 & 42.1 & $<0.001$ \\
\hline
\end{tabular}

and burn exudates (36.7\%) and this is in agreement with $\mathrm{Al}$ Johani et al. (43.0\%) [25]. The univariate logistic regression analysis showed that the risk factors for $P$. aeruginosa infection were age group $\geq 60$ years, hospital stay $\geq 7$ days, cancer, surgery and use of antibiotics $\geq 2$ days. These findings are consistent with those of other studies [28-30].

In the current study the environmental sampling in Egypt and Saudi Arabia showed that $25.0 \%$ and $23.3 \%$ of the samples were positive, which is slightly higher than a previous study in Egypt (19.5\%) [26]. This reflects the fact that $P$. aeruginosa is ubiquitous in the hospital environment. The isolation rate was the highest from suction apparatus tubing in Egypt (57.1\%) and from both suction apparatus tubing and AV machine tubes from Saudi Arabia (42.9\%). This may be explained by the failure of sterilization of suction apparatus tubing and inadequate application of standard precautions for infection control.

On the other hand, $10.0 \%$ and $6.7 \%$ of staff hands in this study were culturepositive in Egypt and Saudi Arabia respectively, which is higher than the rate reported by Crivaro et al. in Italy (3.5\%) [31]. The higher rate of isolation from staff hands in this study could be due to lack of compliance of health care workers to hand-washing practices.

In Egypt antibiotic resistance rates were highest to aztreonam (96.6\%), followed by cefepime (76.3\%) and tobramycin (67.8\%). Kamel et al., also in Egypt, reported that isolates were completely resistant to tobramycin and gentamicin and were sensitive to amikacin (68\%), imipenem and meropenem (52\%) and ciprofloxacin (36\%) [32]. This difference could be attributed to the different rate of use of these antibiotics in different localities. In Saudi Arabia we found antibiotic resistance rates were also highest to aztreonam (96.6\%), but followed by meropenem (72.2\%) and ceftazidime (70.4\%). This is in agreement with a study by Al Johani et al. in Saudi Arabia who found that the resistance significantly increased after 2007, especially for carbapenem (34\% in 2004 to $74 \%$ in 2009), ceftazidime (31\% in 2004 to 36\% in 2009) and ciprofloxacin (33\% to 51\%) [27]. The difference between Egypt and Saudi Arabia in antibiotic resistance patterns was not statistically significant in our study, presumably due to the different rates of use of antibiotics in different countries.

As regards screening for MBLs production in imipenem-resistant strains in Egypt and Saudi Arabia, the high resistance was consistent with an Egyptian study, which found that 10/31 (32.3\%) of strains were MBL-positive [33]. In Saudi Arabia, Al-Agamy et al. found that the prevalence of resistance 


\begin{tabular}{|c|c|c|c|c|c|}
\hline \multirow[t]{3}{*}{ Source/Antibiotic } & \multicolumn{4}{|c|}{ Resistant isolates } & \multirow[t]{3}{*}{$P$-value } \\
\hline & \multicolumn{2}{|c|}{ Egypt } & \multicolumn{2}{|c|}{ Saudi Arabia } & \\
\hline & No. & $\%$ & No. & $\%$ & \\
\hline Patient samples & \multicolumn{2}{|c|}{$(n=59)$} & \multicolumn{2}{|c|}{$(n=54)$} & \\
\hline Colistin & 0 & 0.0 & 0 & 0.0 & 1.00 \\
\hline Imipenem & 29 & 49.2 & 36 & 66.7 & 0.06 \\
\hline Meropenem & 30 & 50.8 & 39 & 72.2 & 0.02 \\
\hline Gentamycin & 31 & 52.5 & 29 & 53.7 & 0.90 \\
\hline Amikacin & 32 & 54.2 & 30 & 55.6 & 0.88 \\
\hline Piperacillin & 34 & 57.6 & 33 & 61.1 & 0.70 \\
\hline Ceftazidime & 37 & 62.7 & 38 & 70.4 & 0.38 \\
\hline Ciprofloxacin & 38 & 64.4 & 28 & 51.9 & 0.17 \\
\hline Tobramycin & 40 & 67.8 & 36 & 66.7 & 0.89 \\
\hline Cefepime & 45 & 76.3 & 35 & 64.8 & 0.18 \\
\hline Aztreonam & 57 & 96.6 & 53 & 98.1 & 0.93 \\
\hline Environment and staff hand samples & \multicolumn{2}{|c|}{$(n=18)$} & \multicolumn{2}{|c|}{$(n=16)$} & \\
\hline Colistin & 0 & 0.0 & 0 & 0.0 & 1.00 \\
\hline Gentamycin & 10 & 55.6 & 10 & 62.5 & 0.68 \\
\hline Amikacin & 11 & 61.1 & 11 & 68.8 & 0.64 \\
\hline Tobramycin & 12 & 66.7 & 11 & 68.8 & 0.89 \\
\hline Imipenem & 12 & 66.7 & 13 & 81.2 & 0.44 \\
\hline Piperacillin & 13 & 72.2 & 12 & 75.5 & 0.83 \\
\hline Meropenem & 13 & 72.2 & 12 & 75.5 & 0.83 \\
\hline Ciprofloxacin & 14 & 77.8 & 10 & 62.5 & 0.45 \\
\hline Cefepime & 16 & 88.9 & 16 & 100.0 & 0.48 \\
\hline Ceftazidime & 18 & 100.0 & 16 & 100.0 & 1.00 \\
\hline Aztreonam & 18 & 100.0 & 14 & 87.5 & 0.21 \\
\hline
\end{tabular}

to carbapenem was $34 \%$, and $22 \%$ of them produced MBLs [34]. ICUs are epicentres of antibiotic resistance and the principal sources of outbreaks of multi-resistant bacteria. The nongenetic causes of antibiotic resistance include excessive consumption of antibiotics by the population. More than $80 \%$ of admitted patients in Egypt are prescribed antibiotics and in many cases without documented proof of infection and this exerts a selective pressure on bacteria
[35] and/or horizontal dissemination [36]. Genetic causes of antibiotic resistance are mutation, over-expression of efflux pumps, loss or modification of porins, and acquired extended-spectrum $\beta$-lactamases [37].

\begin{tabular}{|c|c|c|c|c|c|}
\hline \multirow[t]{3}{*}{ Source } & \multicolumn{4}{|c|}{ MBL-producing imipenem-resistant $P$. aeruginosa strains } & \multirow[t]{3}{*}{$P$-value } \\
\hline & \multicolumn{2}{|c|}{ Egypt } & \multicolumn{2}{|c|}{ Saudi Arabia } & \\
\hline & No. & $\%$ & No. & $\%$ & \\
\hline Patient samples & $16 / 29$ & 55.2 & $36 / 54$ & 66.7 & 0.30 \\
\hline Environment samples & $2 / 3$ & 66.7 & $2 / 3$ & 66.7 & 1.00 \\
\hline Staff hand samples & $0 / 3$ & 0.0 & $0 / 2$ & 0.0 & 1.00 \\
\hline Total & $18 / 35$ & 51.4 & $38 / 59$ & 64.4 & 0.21 \\
\hline$P$-value & \multicolumn{2}{|c|}{$<0.001$} & \multicolumn{2}{|c|}{$<0.001$} & \\
\hline
\end{tabular}




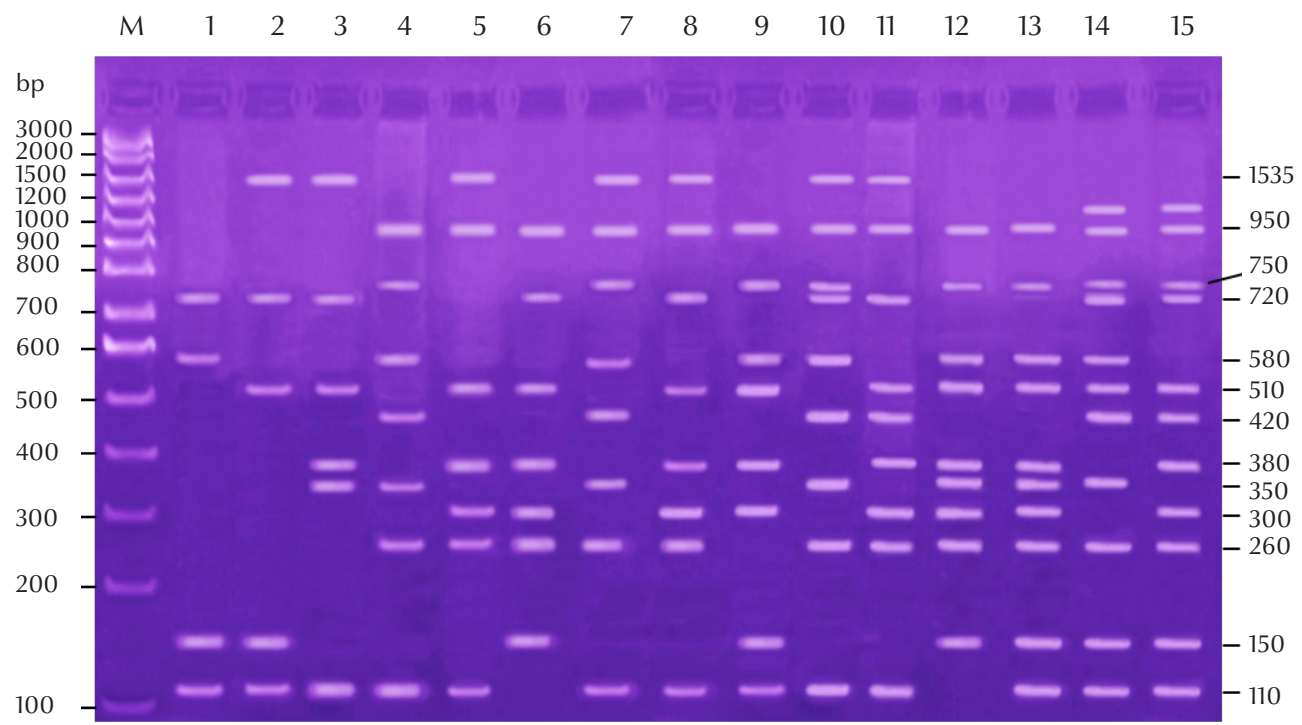

Figure 1 Different 15 enterobacterial repetitive intergenic consensus (ERIC)-PCR patterns of Pseudomonas aeruginosa strains isolated from samples obtained from patients, the environment and staff hands in Egypt. ERIC genotypes of staff hands were ERIC I to III, environmental isolates were IV to IX and XII to XV and patient isolates belong to ERIC VII to XI

Evidence-based prevention strategies targeting specific pathogens should be based on a thorough knowledge of their epidemiology, reservoirs in the ICU and modes of transmission [38]. However, isolation of P. aeruginosa per se is not sufficient to determine the epidemiological importance of the site of isolation, and typing techniques are needed. The numerical discriminatory index for antibiotyping in Egypt and Saudi Arabia gave a low D index (0.712 and 0.728 respectively). This can be explained by the small number of types defined by it (9 antibiotypes in Egypt and 8 Saudi Arabia) and the heterogeneous distribution of the isolates in the groups (22 out of 77 isolates were present in one group in Egypt). This is in agreement with Freitas and Barth who declared that the low discriminatory power of susceptibility tests was not surprising since the power of a method was determined by the number of types defined by it and the relative frequencies of these types [39]. The D index for the ERIC method demonstrated that in

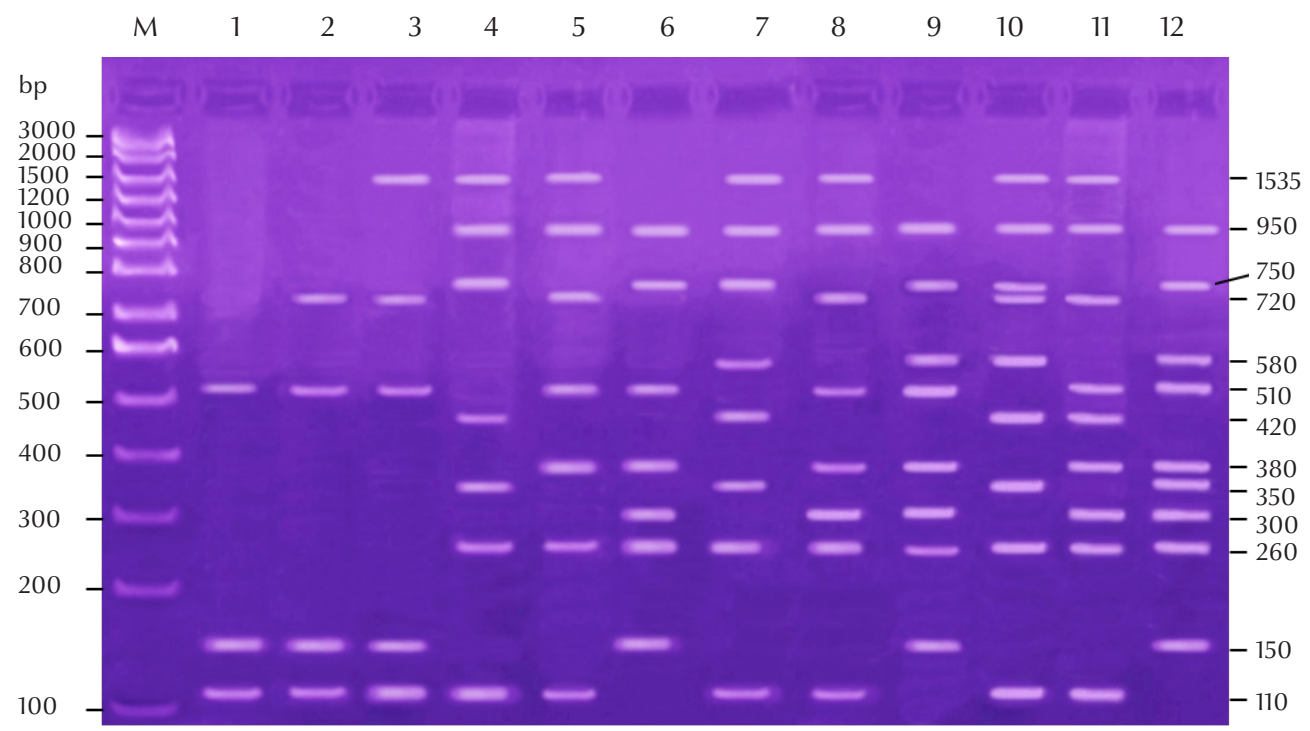

Figure 2 Different 12 enterobacterial repetitive intergenic consensus (ERIC)-PCR patterns of Pseudomonas aeruginosa strains isolated from samples obtained from patients, the environment and staff hands in Saudi Arabia. ERIC genotypes of staff hands were ERIC IV to V, environmental isolates were I to III and VI to XI and patient isolates belong to ERIC VII to XII 

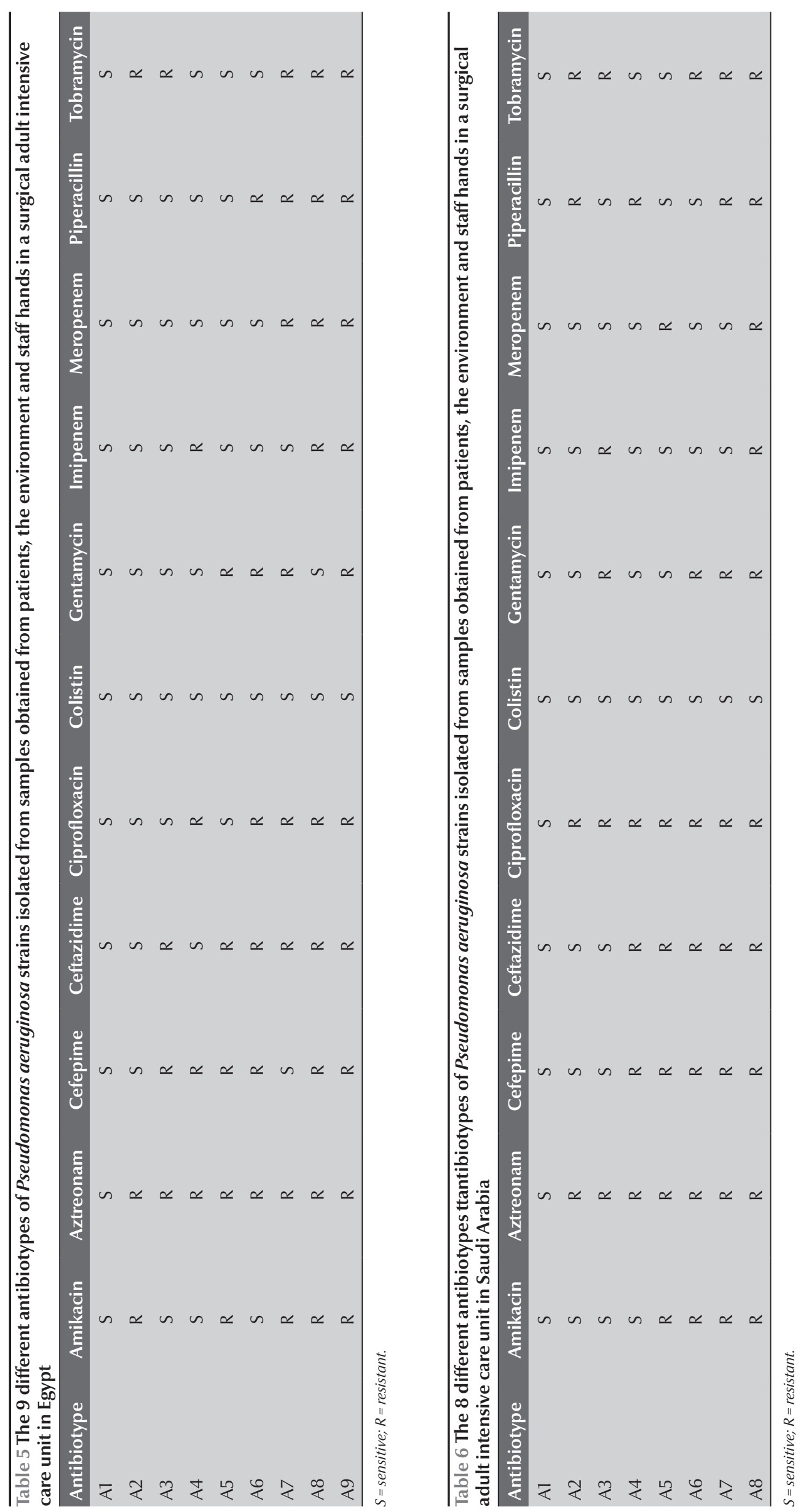


\begin{tabular}{|c|c|c|c|c|c|c|}
\hline \multirow[t]{2}{*}{ Variable } & \multicolumn{3}{|c|}{ Egypt } & \multicolumn{3}{|c|}{ Saudi Arabia } \\
\hline & $\begin{array}{l}\text { No. of different } \\
\text { types }\end{array}$ & $\begin{array}{l}\text { No. of strains } \\
\text { belonging to } \\
\text { most numerous } \\
\text { type }\end{array}$ & $\begin{array}{c}\text { Numerical } \\
\text { discriminatory } \\
\text { index }\end{array}$ & $\begin{array}{l}\text { No. of different } \\
\text { types }\end{array}$ & $\begin{array}{l}\text { No. of strains } \\
\text { belonging to } \\
\text { most numerous } \\
\text { type }\end{array}$ & $\begin{array}{c}\text { Numerical } \\
\text { discriminatory } \\
\text { index }\end{array}$ \\
\hline ERIC & 15 & 26 & 0.801 & 12 & 22 & 0.785 \\
\hline Antibiogram & 9 & 22 & 0.723 & 8 & 18 & 0.728 \\
\hline
\end{tabular}

Egypt and Saudi Arabia, ERIC typing gave a higher $\mathrm{D}$ index (0.801 and 0.785 respectively).

Sharing of certain ERIC types between patient strains may be explained by horizontal transmission from patient to patient, probably from the hands of health care workers or environmental sources. Although P. aeruginosa was isolated from the hands of nursing staff, both typing methods failed to show a direct link with strains isolated from patients. Other studies revealed that staff hands play an important role in its spread in the adult ICU [40] and neonatal ICU [31].

As regards $P$. aeruginosa isolated from environmental sites in our study, 3 sites in Egypt - suction apparatus tubing, AV machine tubes and drainage container-had direct epidemiological relationships with patients. Evacuation of suction apparatus fluid into drainage containers is a possible link that could explain this relationship. In agreement with our study, Yorioka et al. in Japan found that P. aeruginosa was one of the main contaminant bacteria isolated from suction tubes [41]. In Saudi Arabia, 2 sites (suction apparatus tubing and AV machine tubes) had a direct epidemiological relationships with patients. On the other hand, in our study in Egypt and Saudi Arabia, MBL-producing strains were epidemiologically linked to suction apparatus tubing, AV machine tubes and drainage containers, while in Saudi Arabia they linked epidemiologically to suction apparatus tubing and AV machines. This finding can be explained by the fact the MBL genes are harboured in mobile genetic elements and integrons [42]. The same argument can be used to explain why some non-MBL-producing strains shared the same genotype as MBL-producing strains. Also, MBLproducing strains may have originated from the non-MBL strains that acquired the genes through some mobile genetic elements [43].

In summary, this study adds to the evidence that strain typing using the ERIC method is superior to antibiotyping and can increase the efficiency of infection control procedures by determining the patient sources of infections that need to be eliminated and the environmental sources of $P$. aeruginosa that may receive less stringent action. Evidence was also provided that stricter antibiotic prescribing policies and resistance surveillance programmes are needed in Egypt and Saudi Arabia to assist in implementing infection control measures.

\section{References}

1. Driscoll JA, Brody SL, Kollef MH. The epidemiology, pathogenesis and treatment of Pseudomonas aeruginosa infections. Drugs, 2007, 67:351-368.

2. Hidron Al et al. NHSN annual update: antimicrobial-resistant pathogens associated with healthcare-associated infections: annual summary of data reported to the National Healthcare Safety Network at the Centers for Disease Control and Prevention, 2006-2007. Infection Control and Hospital Epidemiology, 2008, 29:996-1011.

3. Livermore DM. Multiple mechanisms of antimicrobial resistance in Pseudomonas aeruginosa: our worst nightmare? Clinical Infectious Diseases, 2002, 34:634-640.

4. Cornaglia G, Giamarellou H, Rossolini GM. Metallo- $\beta$ lactamases: a last frontier for beta-lactams? Lancet Infectious Diseases, 2011, 11:381-393.

5. Cuttelod $\mathrm{M}$ et al. Molecular epidemiology of Pseudomonas aeruginosa in intensive care units over a 10-year period (19982007). Clinical Microbiology and Infection, 2011, 17:57-62.

6. Pitt TL. Epidemiological typing of Pseudomonas aeruginosa. European Journal of Clinical Microbiology and Infectious Diseases, 1988, 7:238-247.
7. Olive DM, Bean P. Principles and applications of methods for DNA-based typing of microbial organisms. Journal of Clinical Microbiology, 1999, 37:1661-1669.

8. Douglas MW et al. Multi-drug resistant Pseudomonas aeruginosa outbreak in a burns unit--an infection control study. Burns, 2001, 27:131-135.

9. Talon D et al. Discriminatory power and usefulness of pulsed field gel electrophoresis in epidemiological studies of Pseudomonas aeruginosa. Journal of Hospital Infection, 1996, 32:135-145.

10. Kersulyte D et al. Comparison of arbitrarily primed PCR and macrorestriction (pulsed-field gel electrophoresis) typing of Pseudomonas aeruginosa strains from cystic fibrosis patients. Journal of Clinical Microbiology, 1995, 33:2216-2219.

11. Syrmis MW et al. Rapid genotyping of Pseudomonas aeruginosa isolates harboured by adult and paediatric patients with cystic fibrosis using repetitive-element-based PCR assays. Journal of Medical Microbiology, 2004, 53:1089-1096.

12. Sharples GJ, Lloyd RG. A novel repeated DNA sequence located in the intergenic regions of bacterial chromosomes. Nucleic Acids Research, 1990, 18:6503-6508. 
13. de Bruijn FJ. Use of repetitive (Repetitive Extragenic Palindromic and Enterobacterial Repetitive Intergeneric Consensus) sequences and the polymerase chain reaction to fingerprint the genomes of Rhizobium meliloti isolates and other soil bacteria. Applied and Environmental Microbiology, 1992, 58:2180-2187.

14. Doebbeling $\mathrm{BN}$ et al. Removal of noscomial pathogens from the contaminated glove, Implications for glove reuse and hand washing. Annals of Internal Medicine, 1998, 109:394-398.

15. Govan JR. Studies on the pyocins of Pseudomonas aeruginosa: morphology and mode of action of contractile pyocins. Journal of General Microbiology, 1974, 80:1-15.

16. Cheesbrough M. Antimicrobial susceptibility testing. In: District laboratory practice in tropical countries. Part 2. Cambridge, UK, Cambridge University Press, 2006:132-143.

17. Collee JG, Miles RS, Watt B. Tests for the identification of bacteria. In: Collee JG et al., eds. Mackie and McCartney practical medical microbiology. New York, Churchill Livingstone, 1996:131-149.

18. Govan JRW. Pseudomonas, Stenotrophomonas, Burkholderia. In: Collee JG et al., eds. Mackie and McCartney practical medical microbiology. New York, Churchill Livingstone, 1996:413-424.

19. Clinical and Laboratory Standards Institute. Performance standards for antimicrobial disk susceptibility tests; approved standard, 10th ed.. Wayne, Pennsylvania, Clinical and Laboratory Standards Institute, 2009 (CLSI document M02-A10).

20. Yong D et al. Imipenem-EDTA disk method for differentiation of metallo beta lactamase-producing clinical isolates of Pseudomonas spp. and Acinetobacter spp. Journal of Clinical Microbiology, 2000, 240:3798-3801.

21. Pinna A et al. An outbreak of post-cataract surgery endophthalmitis caused by Pseudomonas aeruginosa. Ophthalmology, 2009, 116(12):2321-6 e1-4.

22. Versalovic J, Koeuth T, Lupski JR. Distribution of repetitive DNA sequences in eubacteria and application to fingerprinting of bacterial genomes. Nucleic Acids Research, 1991, 19:6823-6831.

23. Viljoen GJ, Nel LH, Crowther JR. Molecular diagnostic PCR handbook. Dordrecht, Netherlands, Springer, 2005.

24. Hunter PR. Reproducibility and indices of discriminatory power of microbial typing methods. Journal of Clinical Microbiology, 1990, 28:1903-1905.

25. Ashour MS et al. Extended spectrum beta-lactamases mediating resistance to extended spectrum beta-lactam antibiotics among Gram-negative bacteria in Cairo. Egyptian Journal of Medical Microbiology, 2003, 12:193-200.

26. Gad GF et al. Characterization of Pseudomonas aeruginosa isolated from clinical and environmental samples in Minia, Egypt: prevalence, antibiogram and resistance mechanisms. Journal of Antimicrobial Chemotherapy, 2007, 60:1010-1017.

27. Al Johani SM et al. Prevalence of antimicrobial resistance among gram-negative isolates in an adult intensive care unit at a tertiary care center in Saudi Arabia. Annals of Saudi Medicine, 2010, 30:364-369.

28. Weber DJ, Raasch R, Rutala WA. Nosocomial infections in the ICU: the growing importance of antibiotic-resistant pathogens. Chest, 1999, 115:34S-41S
29. Ruiz CM, Guerrero PJ, Romero PC. tiología de la neumonía asociada a ventilación mecánica en un hospital clínico. Asociación con co-morbilidad, uso previo de antimicrobianos y mortalidad. [Etiology of ventilator-associated pneumonia in a university hospital. Association with comorbidity, previous use of antibiotics and mortality.] Revista Chilena de Infectología, 2007, 24:131-136.

30. Zavascki AP, Cruz RP, Goldani LZ. Risk factors for imipenemresistant Pseudomonas aeruginosa: a comparative analysis of two case-control studies in hospitalized patients. Journal of Hospital Infection, 2005, 59:96-101.

31. Crivaro A et al. Pseudomonas aeruginosa in a neonatal intensive care unit: molecular epidemiology and infection control measures. Infection Control and Hospital Epidemiology, 2009, 35:1083-1089.

32. Kamel GM et al. Susceptibility pattern of Pseudomonas aeruginosa against antimicrobial agents and some plant extracts with focus on its prevalence in different sources. Global Veterinaria, 2011, 6:61-72

33. Fatma AA et al. Imipenem resistance and BLAIMP gene among hospital strains of Pseudomonas aeruginosa at university hospital in Egypt. Journal of Infection in Developing Countries, 2007, 1:42-47.

34. Al-Agamy $\mathrm{MH}$ et al. High prevalence of metallo-beta-lactamase-producing Pseudomonas aeruginosa from Saudi Arabia. Journal of Chemotherapy (Florence, Italy), 2009, 21:461-462.

35. El-Teheawy MM et al. The pattern of antimicrobial use in general hospitals in Egypt. Chemiotherapia, 1998, 7:387-392.

36. Hocquet $\mathrm{D}$ et al. Genetic and phenotypic variations of a resistant Pseudomonas aeruginosa epidemic clone. Antimicrobial Agents and Chemotherapy, 2003, 47:1887-1894.

37. Pellegrino FLPC et al. Occurrence of amultidrug-resistant Pseudomonas aeruginosa clone in different hospitals in Rio de Janeiro, Brasil. Journal of Clinical Microbiology, 2002, 40:24202424.

38. Trautmann M, Lepper PM, Haller M. Ecology of Pseudomonas aeruginosa in the intensive care unit and the evolving role of water outlets as a reservoir of the organism. American Journal of Infection Control, 2005, 33(5 Suppl.):S41-S49.

39. Freitas AL, Barth AL. Typing of Pseudomonas aeruginosa from hospitalised patients. Comparison of susceptibility and biochemical profiles with genotypes. Brazilian Journal of Medical and Biological Research, 2004, 37:77-82.

40. Foca $\mathrm{M}$ et al. Endemic Pseudomonas aeruginosa infection in a neonatal intensive care unit. New England Journal of Medicine, 2000, 343:695-700

41. Yorioka K, Oie S, Kamiya A. Microbial contamination of suction tubes attached to suction instruments and preventive methods. Japanese Journal of Infectious Diseases, 2010, 63:124-127.

42. Poirel $L$ et al. Characterization of class 1 integrons from Pseudomonas aeruginosa that contain the blaVIM-2 carbapenem-hydrolyzing beta-lactamase gene and of two novel aminoglycoside resistance gene cassettes. Antimicrobial Agents and Chemotherapy, 2001, 45:546-552.

43. Rossolini GM. Acquired metallo-beta-lactamases: an increasing clinical threat. Clinical Infectious Diseases, 2005, 41:1557-1558. 